\title{
Unglittering Gold Schemes in India
}

\section{A. Arun Kumar ${ }^{1}$ (D) Daravath Vikas Nayak ${ }^{2}$ D}

Published online: 29 July 2021

(C) International Atlantic Economic Society 2021

\section{JEL Classification $\mathrm{G} 28 \cdot \mathrm{H} 83 \cdot \mathrm{I} 31 \cdot \mathrm{M} 5 \cdot \mathrm{O} 16$}

Indians are gold lovers and invest a major portion of their finances in buying gold ornaments which reflect status and provide a safe investment option. However, most of the gold in Indian households lies idle in bank lockers (Kumar, Arthshastra Indian Journal of Economics \& Research, 2014), safes and vaults making it a dead investment (Laurence, International Advances in Economic Research, 2000). The demand for gold in India has resulted in a surge in gold imports which inversely affects the value of the rupee and is creating an outflow of currency into world trade (Laurence, International Advances in Economic Research, 2000). The idleness and unproductive use of gold in India is creating a gap in the Indian economy (Panda et al., Indian Journal of Finance, 2016). Gold monetization can help fill the gap without importing gold from other countries (D'Souza, Economic and Political Weekly, 2015). Realizing the need to increase the circulation of gold in the market and to reduce gold imports, gold prices and the burden on the Indian economy, the Government of India (GoI) introduced initiatives such as gold bonds, gold monetization and gold coin schemes in 2015 (Government of India, Gold Monetization Scheme, 2015, https://www.dea.gov.in/gms2015) (Online Supplemental Appendix Table 1). A thorough literature review revealed studies related to the importance of gold monetization for macroeconomic stability, the emotional attachment of Indians to gold, and bankers' and refineries' perception of gold monetization policy in India (Singh et al., IIMB WP No. 534, 2017 https://repository.iimb.ac.in/bitstream/123456789/7725/1/WP_IIMB_534.pdf). No existing literature was identified explaining the performance of these gold bond schemes (GBSs) and underlying reasons for this performance in India. The present research attempts to fill this research gap and study the reasons underlying the non-performance of GBSs in

\section{A. Arun Kumar}

arunkumar@ifheindia.org

1 Centre for Management Studies, ICFAI Law School, The ICFAI Foundation for Higher Education (A Deemed-to-be University u/s 3 of the UGC Act, 1956), Donthanpally, Shankerpally Road, Hyderabad 501203 TG, India

2 Department of Commerce, Osmania University, Hyderabad 500007 TG, India 
India implemented in 2015 by looking at trends in gold prices (Bank Bazaar, Gold Rates Historical Data for India, https://www.bankbazaar.com/gold-rate/gold-rate-trend-in-india. html), gold imports (Gem \& Jewelry Export Promotion Council, Analytical Reports, https://www.gjepc.org/statistics.php\#month-report) and current account deficit (Trading Economics, India Current Account to GDP, https://tradingeconomics.com/india/currentaccount-to-gdp) in India (Online Supplemental Appendix Table 2). The present study is based on secondary data and is limited to GBSs in India only.

The present study revealed that even after the introduction of GBSs in India in 2015, there was a considerable increase in gold prices reaching a record high of 56,590 rupees in 2020, while the average gold price for the year was 48,652 rupees. The increase in gold prices indicated that GBSs could not attract the attention of investors when compared to buying physical gold. However, gold imports declined in 2015, 2016 and 2020. Further study of the reasons for this trend revealed that the decline in gold imports in India in 2016 was due to a fall in domestic demand caused by the jewelers' strike against the imposition of a $1 \%$ excise duty on non-silver jewelry, and a lack of global price parity (The Hindu Business Line, Gold Imports Down 10\% in 2015-16 as Demand Shrinks, 2018, https://www. thehindubusinessline.com/markets/commodities/gold-imports-down-10-in-201516-asdemand-shrinks/article8566391.ece). The decline in gold imports in 2017 was a direct result of demonetization enacted by the GoI in November 2016. The decline in gold imports in 2020 can be attributed to the strict nationwide lockdown imposed by the GoI due to the Covid-19 pandemic which led to a decrease in retail demand for gold. Contraction of the current account deficits in 2016, the year immediately after the introduction of GBSs in India, and in 2019 was a result of lower trade deficits due to a decline in exports and imports of goods. The present study clearly demonstrated that gold monetization schemes did not facilitate a decline in gold prices, gold imports and the current account deficit as intended. Trends in gold prices, gold imports and current account deficit were affected by other underlying reasons and not solely because of the GBSs.

The drawbacks of GBSs include a maximum purchase limit of $500 \mathrm{~g}$ per person per year and redemption only after eight years. Opting out early bears high liquidity risk. Though bonds are tradable through dematerialised accounts, considerably less taxable interest $(2.75 \%)$ is paid to the investor. Gold bond returns are far exceeded by the market value. Default risk is an additional priority. Investors bear a risk of uncertainty regarding successive investment amounts under this scheme. Other types of investments have more predictable liquidity risk compared to GBSs. In gold monetization schemes, once deposited, jewelry cannot be returned in the same state. Most investors are not very familiar with GBSs while others, though they have an idea, fear the returns. Lack of proper infrastructure, high processing fees and income tax risk are other drawbacks. Thus, GBSs have not attracted the attention of investors in India. GBSs should be marketed widely to reach every individual in the country.

The main motive of gold schemes is to reduce the price of gold, reduce gold imports and avoid the burden on the current account deficit. However, GBSs have not succeeded in these goals. Investors are not motivated to participate in these schemes because of the rigid terms, conditions, and features of the GBSs. Another important barrier that may hinder GBSs is the emotional bond between Indians and gold which will likely prevent the schemes from ever working as intended. Hence, several measures must be taken by the GoI to facilitate these schemes successfully. 
To increase gold scheme visibility, the GoI should increase the interest rate as well as reduce the maturity period of the schemes by investing the amounts from GBSs in high-performing stocks yielding maximum profits which can be paid as interest. Small investors and low-income groups can invest in GBSs to increase the gold liquidity piled up in the rural areas of India. Creating awareness among Indian working women, offering special schemes on specific occasions, encouraging banks to publicize GBSs, emphasizing gold as an investment for business and preparing a hedging strategy to overcome the fluctuations in gold prices for GBSs can enhance investments in GBSs. A strong mediation system with good publicity could facilitate the success of these schemes.

Supplementary Information The online version contains supplementary material available at https://doi.org/10.1007/s11294-021-09826-3.

Publisher's Note Springer Nature remains neutral with regard to jurisdictional claims in published maps and institutional affiliations. 